Monika Matušovičová* Denis Matušovič ${ }^{* * *}$
JEL Classification: G01, G10, G12, G15

Article review

https://doi.org/10.32910/ep.70.5.6

\title{
RECOVERY OF THE EUROPEAN ASSET MANAGEMENT TEN YEARS AFTER THE FINANCIAL CRISIS
}

The article is analyzing the current situation of the European asset management after the financial crisis 2007-09 and compares the difference to the dot com bubble in 2000-03. It compares European assets under management with the global situation as well as European macroeconomic indicators including gross domestic product and employment. The analysis is supported by the comparison of reactions of the financial market and gross domestic product to dot com bubble and financial crisis. Results of the analysis show that the industry has fully recovered from the financial crisis with the European assets under management well above pre-crisis peak. Equity funds are nowadays the most preferred type of mutual fund in the Eurozone followed by bond funds. That points to increased and renewed risk appetite of investors after the crisis. In the end is the article supported by other important aspects of European asset management as changing monetary policies of European Central Bank and Federal Reserve.

Keywords: European asset management, financial crisis, mutual funds, dot com bubble, macroeconomic analysis

* M. Matušovičová, Ph.D., Associate Professor, Department of Marketing, Faculty of Commerce, University of Economics in Bratislava, Slovakia (e-mail: monika.matusovicova@euba.sk).

** D. Matušovič, MSc., Department of Banking and International Finance, Faculty of National Economy, University of Economics in Bratislava, Slovakia (e-mail: denis.matusovic@euba.sk).

The paper was received on April 23rd, 2018. It was accepted for publication on January 17th, 2019. 


\section{INTRODUCTION}

Carhart (1997) states that most asset managers are not able to outperform the market in the long term as well as that no market can go up forever without occasional smaller or bigger corrections. Past two decades have confirmed this statement. European asset management has changed after the global financial crisis from 2007 to 2009. The whole industry is nowadays more dynamic and flexible to changes in terms of new European regulation, passive investing and continuous digitalization (Arner, Barberis and Buckley, 2015). Global financial crisis substantially decreased assets under management (AUM) in Europe peaking in 2008. The situation started to change in 2009 because of the fast response from Federal Reserve (FED) and European Central Bank (ECB) in terms of unconventional monetary policies. Another correction came with Greece in 2011 when European asset management was affected more than the rest of the world (De Santis, 2012). Since then came a strong recovery and all-time highs, mainly in equity funds.

The goal of the article is to quantify the scope of the recovery of the European asset management after the financial crisis. The article compares financial market performance with real economy performance. It also points to the difference between dot com bubble and financial crisis with similar negative financial market performance but different scope of recessions in real economy measured by gross domestic product and employment rate.

European asset management showed its strength with Brexit in 2016 which did not affect the growth of the industry although it is yet to be seen how the new cooperation between the UK and European Union will look like (Pisani-Ferry, 2016). Bond yields are historically very low across whole Europe and the inflation is not reaching the European Central Bank's goal of 2\% yet. Changes in the monetary policies are expected from FED and ECB. Federal Reserve is steadily increas-

ing interest rates since December 2015 and European Central Bank is expected to end quantitative easing (QE) in September 2018. Both these processes are signaling the end of the very accommodative monetary policy around the world since the financial crisis.

\section{LITERATURE REVIEW}

One of the most complex areas that is affecting European asset management is the regulation of the European Union with the overall goal to make the industry more secure, transparent and easier to understand for the retail investor. 
Mutual funds can be divided in categories of UCITS and Non-UCITS funds. UCITS funds are approved by local regulator and it is also possible to sell them in every country of European Union without the need for individual approval of each member state. With the approval of this directive, the amount of needed bureaucracy was decreased and whole legislation in terms of European Union has been simplified (Matusovic and Matusovicova, 2010). In terms of asset management, two main directives are in force, 2004/39/EC - MiFID and 2001/108/EC - UCITS (The Undertakings for Collective Investment in Transferable Securities), published in official journal EUR-Lex.

First and second directive of UCITS in the eighties and nineties of the last century were not approved in whole European Union also because of an inadequate harmonization of legislation. Situation changed when directive UCITS III was approved and introduced into praxis (in December 2001) followed by UCITS IV (July 2011). In April of 2014 European parliament approved directive UCITS $\mathrm{V}$ that had to be firstly approved by all member states and then implemented in national law over the years 2016 and 2017 (European Commission, 2018).

UCITS IV brought many changes and innovations into mutual fund sector area in European Union including (Chovancova and Zofcak, 2012):

- possibility to create sub-funds to mutual funds

- more detailed adjustments in terms of organizational requirements aimed at asset management companies

- management company passports that allows complex cross-border management of funds by asset management companys from one country to another in the European Union

- possibility to merge standard mutual funds, cross-border administration of standard mutual funds and a permission to merge assets of funds that were previously invested by different subjects on the market (so called asset pooling)

- possibility of an establishment of the structure master - feeder account as another form of asset pooling

- elimination of deficiencies in previously used prospectus that was aimed to give investors information about risks, fees and expected returns

- changes in the structure and system of classification - more detailed classification of funds in terms of UCITS and Non-UCITS funds

The UCITS directive covers big amount of different types of investment funds and brings complex regulations including activities that were not covered previously. Directive modifies most of the rules regarding management of alternative investment funds - including requirements on own capital, possible conflict 
of interests and the transparency against investors. It is especially focused on two problems. First is the use of financial leverage in funds and second is the acquirement of majority of shares in other companies through mutual funds. Directive also keeps in mind the fact that managers of small specialized alternative investment funds would be excessively overwhelmed by this kind of regulation. Therefore if asset management company manages only funds that are valued under 100 million EUR, only formal registration and reporting to supervising institution is required on yearly basis (Cilikova and Ambra, 2013).

Education of investors is a very important component of the client's security. If sufficient education in the financial area is secured, then this knowledge can help the investor to better understand investment products and investment processes. Investment knowledge can be essential in financial planning and warning the client before potential problems. Selecting appropriate investment and education programs can provide the potential investor with answers for their questions, useful tools for valuation of the investments and contacts of renowned professionals in the area of financial services. Supervisory and regulation institutions have unique place in terms of providing independent and objective information to potential investors. High-quality education in the area of the investment as the component of client's protection can lead to an expansion of the financial market with investors who are well informed and therefore can invest with higher level of confidence (Tidwell, 2014).

Directive MiFID 1 (Markets in Financial Instruments Directive), approved in year 2004 and introduced to praxis in November 2007 is also actual nowadays. Its main targets are creation of equal conditions for investment services in the area of European Union, increase of the client's protection and market's transparency, introduction of the categorization of clients as well as overall more effective financial market. Successor of this directive known also as MiFID 2 was approved in European parliament in April 2014. MiFID 2 is scheduled to be in force from 3 January 2018. Except of other areas, should this new directive also be aimed on the market of financial derivatives (European Commission, 2017).

\section{MATERIALS AND METHODS}

The economic theory quantifies the close relationship between stock equities (financial market) and gross domestic product (real economy) as one of its fundamentals (Levine and Zervos, 1998). The articles analyze this relationship during the dot com bubble, financial crisis and afterward recovery.

Gross domestic product (GDP) of the Eurozone (EU19) and employment rate (EMR) of EU19 are main indicators of the macroeconomic analysis although 
wider numbers of European Union (EU28) are analyzed as well. German equity index DAX30 is the indicator of stock market performance. It has long-term data history as well as reflecting the performance of the strongest European economy and member of the Eurozone with export-oriented open economy. All data for the econometric model are either from Eurostat (GDP, employment) or Bloomberg (DAX30) and were processed in the econometric software Gretl.

Data for the econometric model consists of time series with 71 observations from the first quarter of 2000 to the third quarter of 2017 for the latest available data. The linear regression with OLS (ordinary least squares) is used in the form of:

$$
D A X 30_{i}=\beta_{0}+\beta_{1} G D P E A 19_{i}+E M R E A 19_{i}+\varepsilon_{i}
$$

The article consists of numerical and verbal analysis as well as of world-wide asset management with the focus on the European asset management. The analysis is supported by the newest available data from EFAMA 2016 (European Fund and Asset Management Association) and other renowned sources. Data regarding assets under management in mutual funds were converted to US dollar to abstract from different currencies. Exchange rates were fixed on the spot exchange rate applicable for each selected period.

\section{RESULTS}

This part of the article is focused on the econometric model and the relationship between stocks, GDP and employment rate. Difference between Eurozone and European Union GDP and employment rate is very small at percentage basis. Similar situation is also in terms of employment rate. Both indicators are showing steady growth if it's abstracted from seasonal fluctuations. GDP of European Union as well as Eurozone increased from 2000 to 2017 by $64 \%$ or annualized $2.79 \%$. The employment rate in the Eurozone increased from 143 million to 159 million workers (11\% increase) and in the European Union from 217 million to 241 million workers (11\% increase as well). Since the correlation between the Eurozone and European Union is very high only Eurozone indicators are used in further analysis since they are denominated only in EUR as well as DAX30. 
Fig 1 .

\section{GROSS DOMESTIC PRODUCT (QUARTERLY, EUR MILLIONS) AND EMPLOYMENT RATE (THOUSANDS)}

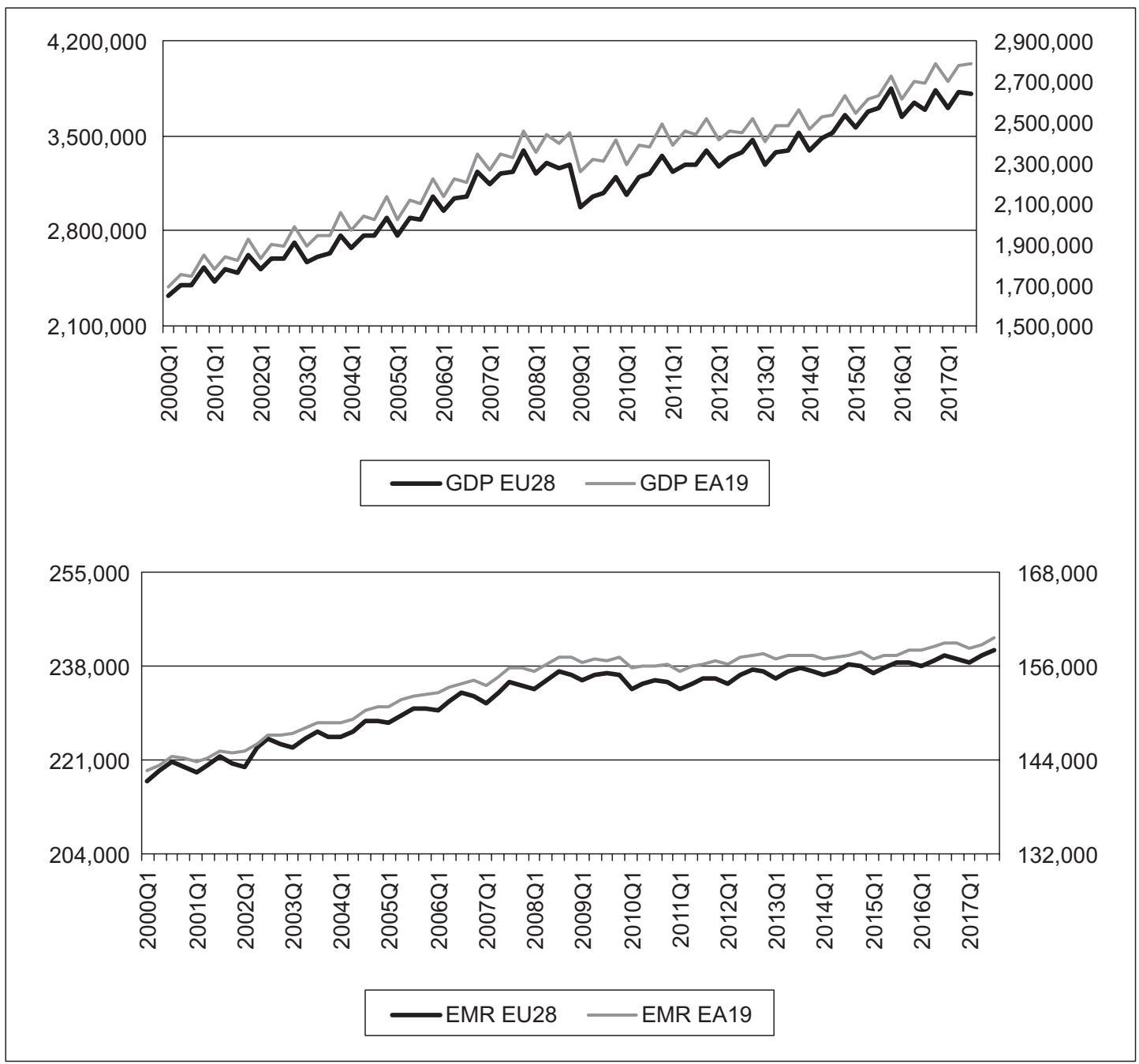

Source: own processing per available data from Eurostat, 2017

Correlation matrix adds Germany's DAX30, one of the best performing European equity indexes that is denominated in euro. Its correlation with GDP of EU19 is $74 \%$ and with employment rate of EU19 is 58\%. GDP and employment rate in EU19 have a mutual correlation of $96 \%$. 
Fig 2.

CORRELATION MATRIX BETWEEN DAX30 AND EU19 INDICATORS

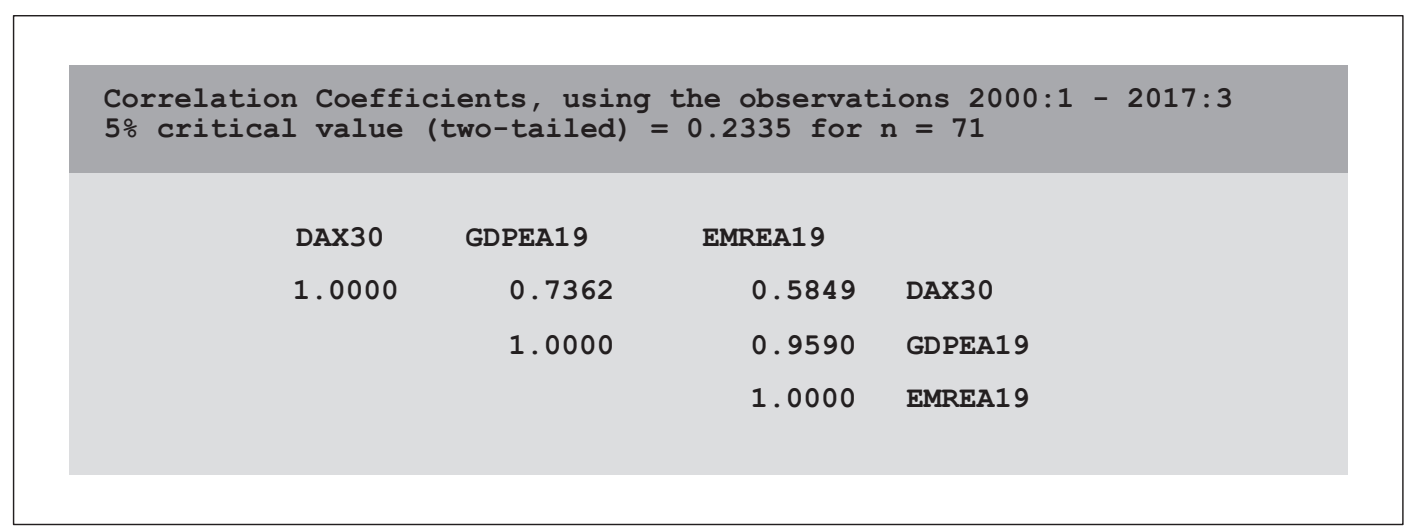

Source: own processing per available data, Gretl

Fig 3.

\section{AGGREGATED CHART OF ANALYZED INDICATORS}

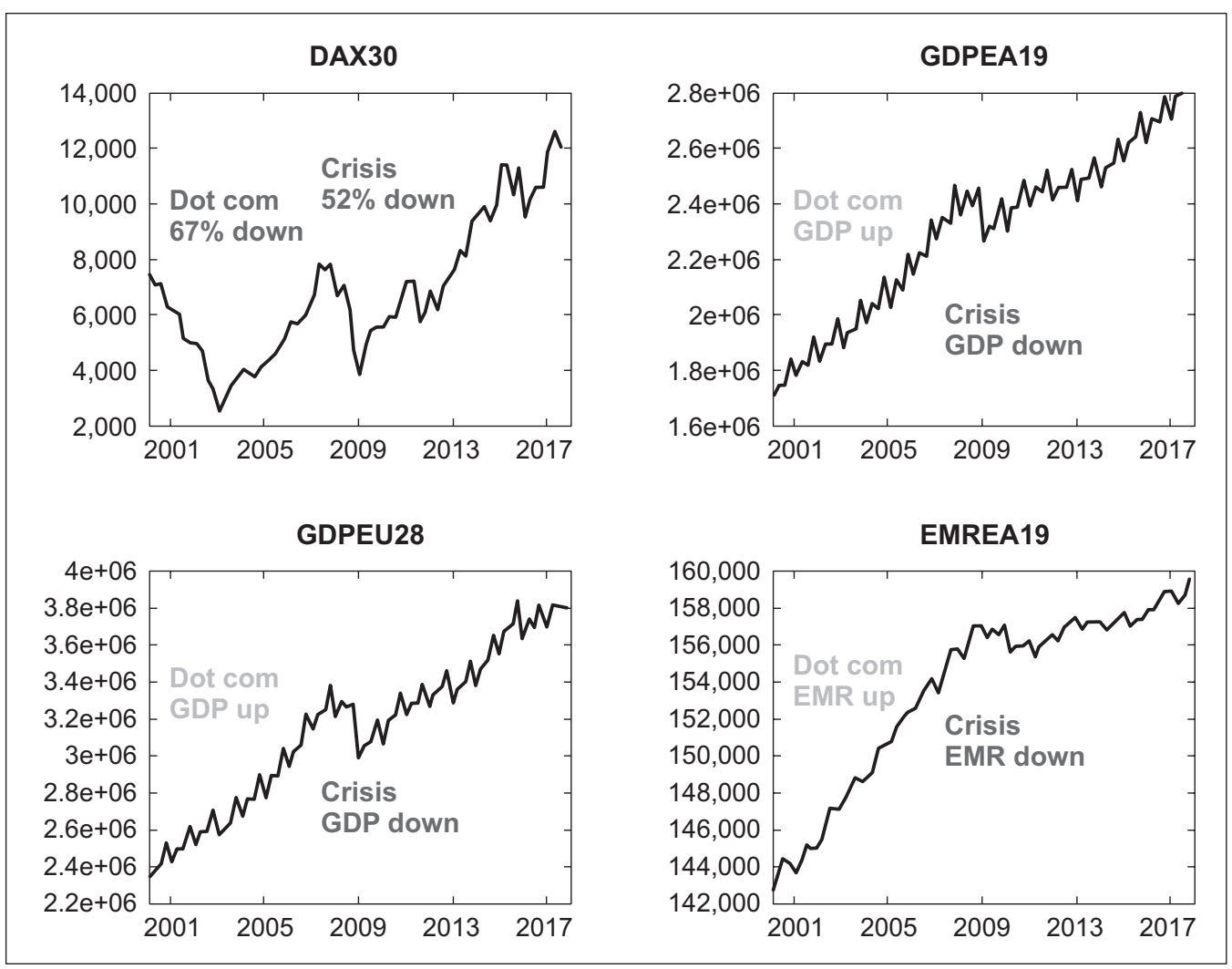

Source: own processing per available data, Gretl 
The important fact from the quantified data shows the difference between dot com bubble that started in 2000 and global financial crisis that started eight years later. In both cases DAX30 fell substantially. From Q1 of 2000 to Q1 of 2003 DAX30 fell by 67\% and GDP of the Eurozone during the same period increased by $11 \%$. On the other hand, in the case of financial crisis from Q4 2007 to Q1 2009 DAX 30 fell by $52 \%$ and GDP of the Eurozone decreased by $8 \%$.

As expected, the stock market in the analyzed period was much more volatile with $10,7 \%$ standard deviation of year over year performance than the GDP with 3,6\% standard deviation. As visualized in Figure 4. Although DAX 30 is much more volatile, it catches up with GDP performance over the long term because of strong recovery periods.

Fig 4 .

\section{PERCENTAGE PERFORMANCE OF DAX 30 AND EUROZONE'S GDP}

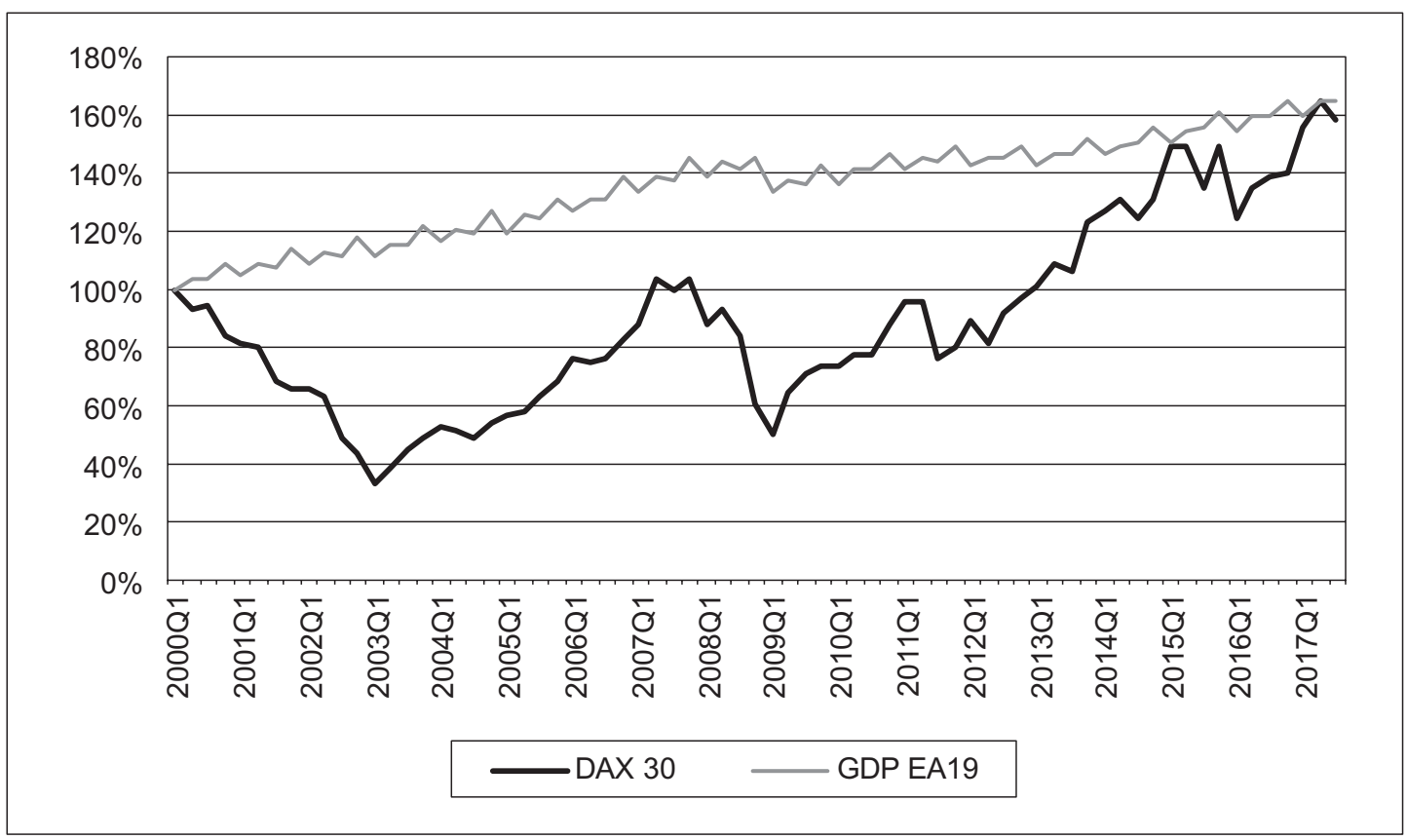

Source: own processing per available data

The dot com bubble did not affect GDP as the financial crisis, although the drop in the DAX30 was bigger by 15\% (Kouki, Belhadj and Chikhaoui, 2018). Nevertheless, DAX30 advanced from 2000 to 2017 by 57\%, which is 2,54\% per annum, annualized dividends included, since it is a performance type index. 
Fig 5:

\section{ORDINARY LEAST SQUARES ECONOMETRIC MODEL}

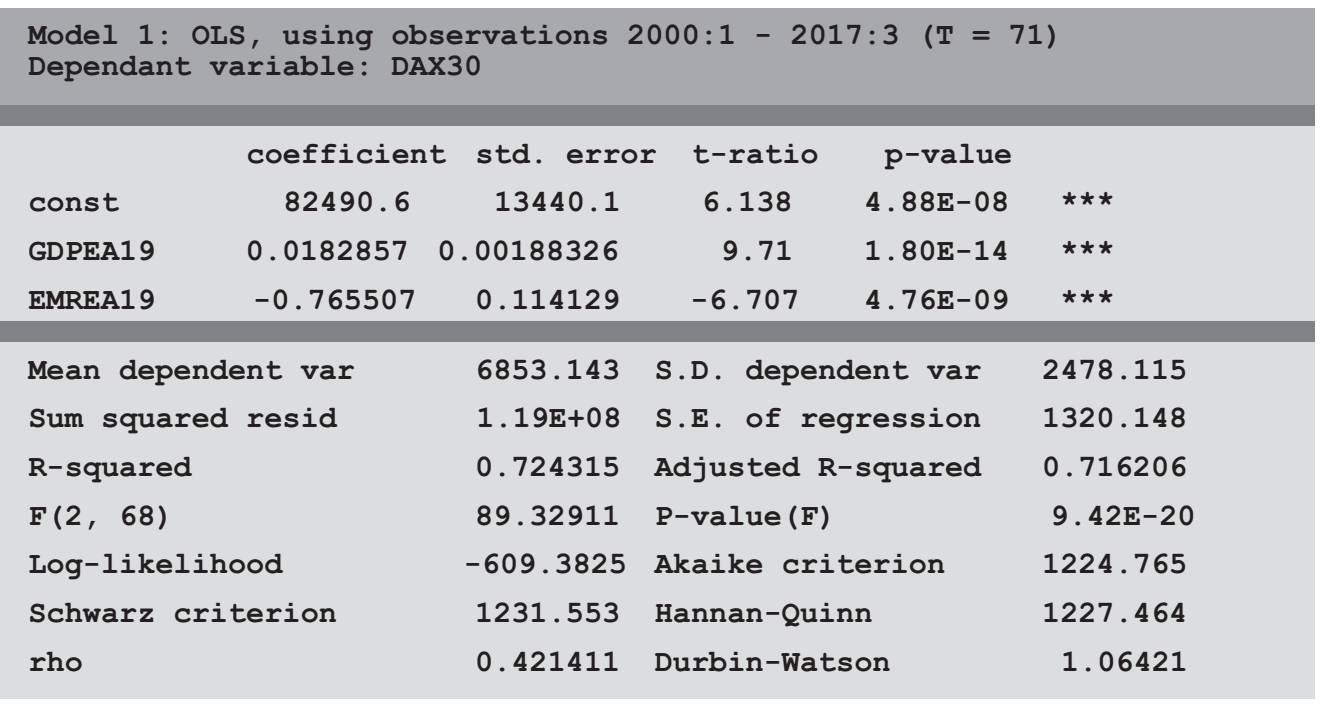

Source: own processing per available data, Gretl

The econometric model of the linear regression has DAX30 as a dependent variable and GDP plus and employment rate as independent variables. Number of observations is 71, from 2000 to 2017 on quarterly basis. The model is showing promising positive relationship between GDP growth and stocks growth which is one of the important fundamentals in the economic theory. On the other hand, employment rate is not showing positive correlation what can be caused by two reasons. Firstly, the higher GDP growth and subsequently higher stock prices can be reached not just by higher employment but also by higher productivity, which is probably the case in Germany. The employment rate is also supported by new emerging members of the European Union and Eurozone. Secondly, the employment rate was not reacting at dot com bubble in any way and the consequences of the financial crisis were lower as in case of GDP as well. It can be stated that the employment rate has lower elasticity than stock prices and gross domestic product. All this indicates that there is a stronger economic relationship between stocks and gross domestic product than between stocks and employment rate.

The model is statistically considered pretty solid with significant p-values for analyzed independent variables as well as for the whole model, R-squared and adjusted R-squared reached over $70 \%$ which is considered as a good result. T-ratios 
for variables and F-ratio for model as well as White's test for heteroscedasticity did not point to any marginal problems.

\section{DISCUSSION}

Asset management in the world is in very good shape nowadays. Total AUM (assets under management) in worldwide investment funds at the end of 2015 stood at more than 40.6 trillion USD. It increased by $13.7 \%$ on year to year basis in comparison to year 2014. From the end of 2006 global AUM increased from 18.3 trillion USD to 40.6 trillion USD which represents $122 \%$ increase. Equity funds were represented at the end of 2015 with $41 \%$ of total AUM. Bond funds followed with $21 \%$ and multi-asset (mixed) funds represented 19\% of total assets. Money market funds represented $12 \%$ of total assets under management and $7 \%$ were other smaller categories of mutual funds (EFAMA, 2016).

Fig 6:

WORLD-WIDE AUM IN USD TRILLION (2006-2015)

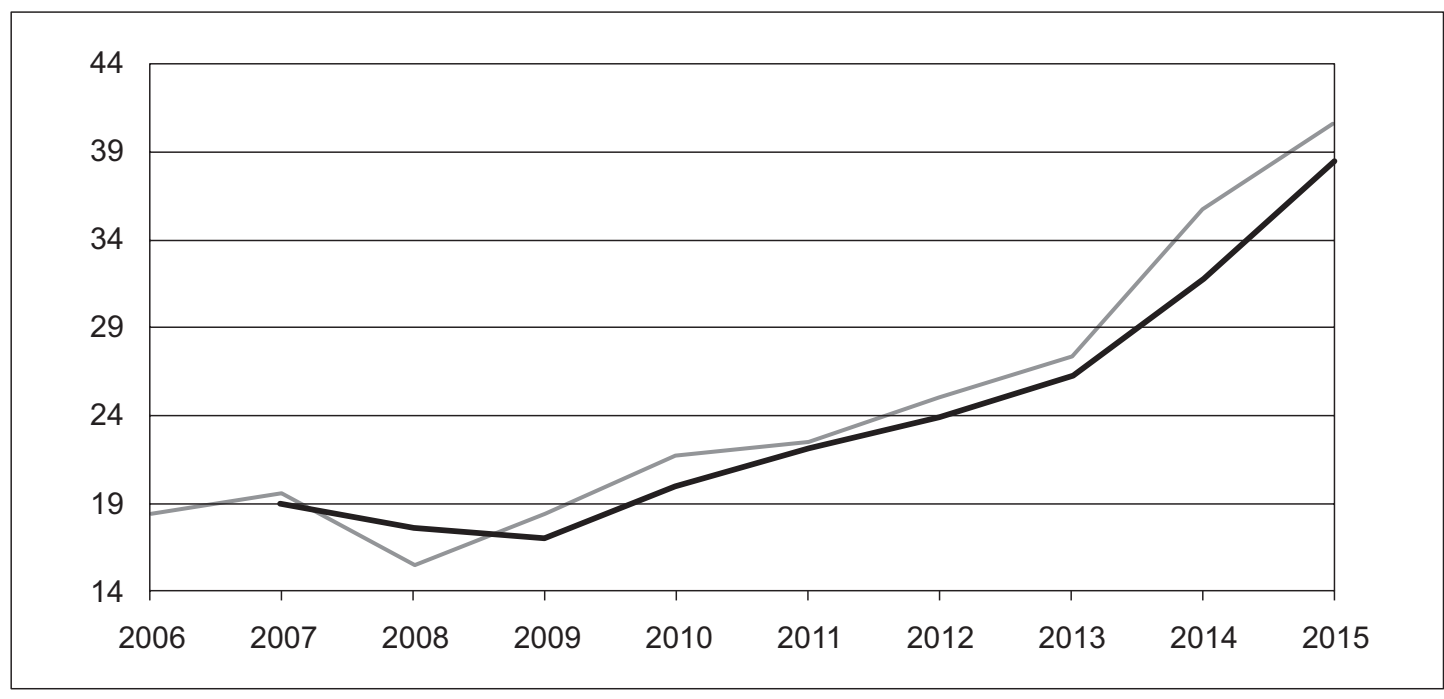

Source: own processing per available data from EFAMA (2011, 2013 and 2016)

It is important to note that global AUM decreased by $21 \%$ as the result of global financial crisis in 2008. Mutual funds partially recovered in 2009 and increased over 2007 high levels in 2010. After Greece crisis in 2011 and slower 
AUM growth, fast recovery started and got to all-time highs every year from 2012 . Assets under management are nowadays above the moving average (grey dot line) which can, in terms of technical analysis, be seen as overvaluation.

This very positive development is also influenced by quantitative easing (QE) programs from European Central Bank, Bank of England (BOE) and Federal Reserve (FED QE until late 2014). The positive impact of the ECB, BOE and FED policies could only be temporally, especially because the launch of the QE reduced room for maneuver for further monetary stimulus (EFAMA, 2016).

As a result of unconventional monetary policy, interest rates are considerably low. European Central Bank is holding its main rate at $0 \%$ and in terms of forward guidance it will continue to do so for a longer period. BOE has its main bank rate at $0.50 \%$. Inflation plays a very important role as well because it is one of the main goals (or even only goal for some central banks). With steadily increasing inflation in United States of America, Federal Reserve is slowly increasing rates with one rate hike in 2015, two in 2016 and another three rate hikes in 2017. Further rate hikes will depend on new economic development and global uncertainties (Yellen, 2017). Federal Reserve interest rate is, as of February 2018, 1.50\%.

Another important thing is how are assets under management allocated over the world. Most AUM is in the United States of America (19.317 billion USD, 48\%) followed by Europe (13.906 billion USD, 34\%). Emerging markets are represented by $7 \%$ (2.877 billion USD) and other regions (Japan, Canada and Australia) are represented by $11 \%$ (4.461 billion USD). USA and Europe together represent $82 \%$ of global AUM and developed countries represent 93\% of global assets under management (Carroll, Sciamarelli and Delbecque, 2016).

\subsection{European asset management}

Global asset management including Europe and CEE region is in very good shape nowadays. The net assets held by European investment funds broke through the USD 14 trillion barrier at the end of 2015. Five years earlier, UCITS and AIF net assets only totaled USD 9.3 trillion. The net sales of UCITS and AIF funds reached all-time high of USD 830 billion in 2015. Average net sales of mutual funds from 2009 to 2014 were only USD 337 billion. Increasing household's purchases of mutual funds are behind this trend as well in form of direct purchases or indirectly through insurance and pension plans. Cross-border funds are continuously having bigger roles in the growth of the industry as well (EFAMA, 2016).

European investment fund assets increased by $10.8 \%$ in 2015 to USD 14.4 trillion. Investment fund assets stood 76\% higher at the end of year 2015 compared 
to 2006. The growth in net assets was supported by strong net sales of investment funds. This was all achieved despite lower economic growth, concerns about deflation and geopolitical tensions (Carrol, Sciamarelli \& Delbecque 2016).

Fig 7.

EUROPEAN (RIGHT AXIS) AND GLOBAL AUM (LEFT AXIS) IN TRILLION USD (2006-2015)

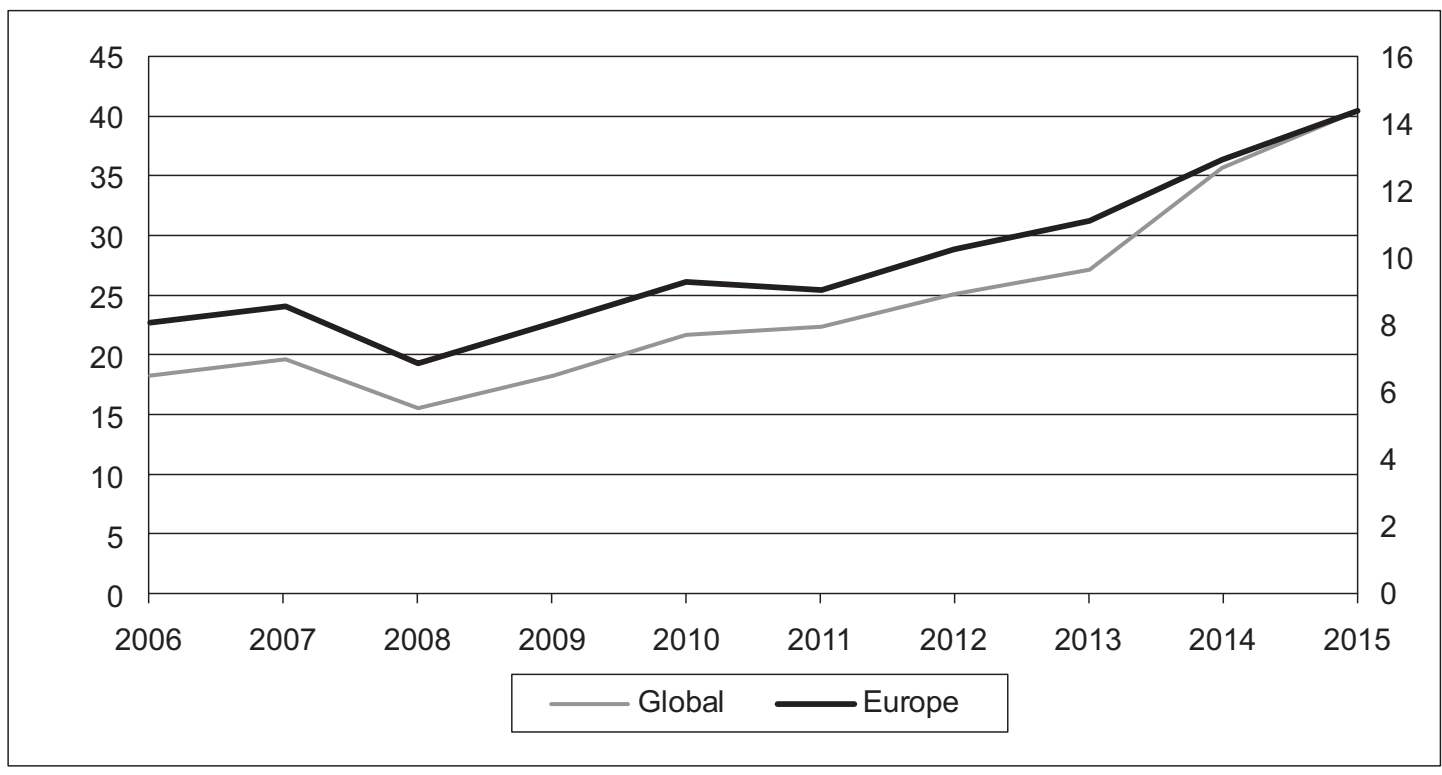

Source: own processing per available data from EFAMA (2011, 2013 and 2016)

European growth of $76 \%$ is lower than global growth of $122 \%$ (in terms of AUM from 2006 to 2015). Faster global growth of AUM was caused mainly by faster growth in the USA and emerging markets. Many different sectors are investing in mutual funds. Majority of net acquisition of investment funds in 2015 in the Europe was purchased by other financial institutions (38\%), households (32\%), insurers and pension funds (24\%). Just $6 \%$ of net acquisition was purchased by others. Higher purchases from the sector of households point to overall better asset management outlook. Households were very cautious with investment funds for longer periods of time after crisis but nowadays they are increasing investments in the mutual funds just like other sectors (EFAMA, 2016).

Carrol, Sciamarelli \& Delbecque (2016) states that at the end of 2015, euro area households held $40.6 \%$ of their financial wealth in bank deposits and $10.4 \%$ in investment funds. In the United States of America bank accounts represented 
only $17.3 \%$ of household financial health. It confirms one of well-known facts that in USA it is more common for individual investors to invest in stock equities and mutual funds than in Europe. On the other hand, it confirms that there is still big potential for development of the asset management in Europe. Lemeshko and Rejnus (2015) note that this is even more true in CEE region where local markets are well away from being fully saturated.

Equity mutual funds are mostly preferred in the Europe with $41 \%$ market share followed by bond funds with $28 \%$ market share. Multi-asset funds have $16 \%$ market share and money market mutual funds have the lowest market share (15\%). As Markowitz (1991) states the diversification is one of the most important investment principles and latest data confirms that the European investor is well diversified. Equity funds are currently achieving highest returns from all categories and are therefore in demand from the side of retail and institutional investors. Low interest rates and accommodative monetary policies all around the world are making bond funds and money market funds less attractive for investors (EFAMA, 2016).

\subsection{Growth correlation and biggest markets}

It is well-known fact in the theory that AUM is correlated with stock equities and gross domestic product. Gladis (2009) states that there is positive correlation between AUM, stocks and GDP. It means that if stocks and GDP increase than AUM should increase as well. Theory states that there might be some time lag between equity prices and gross domestic product figures because stocks are quicker in pricing future estimations and forecasts than GDP. 
Fig 8 .

\section{CORRELATION BETWEEN EUROPEAN AUM, STOXX EUROPE 600 AND REAL GDP}

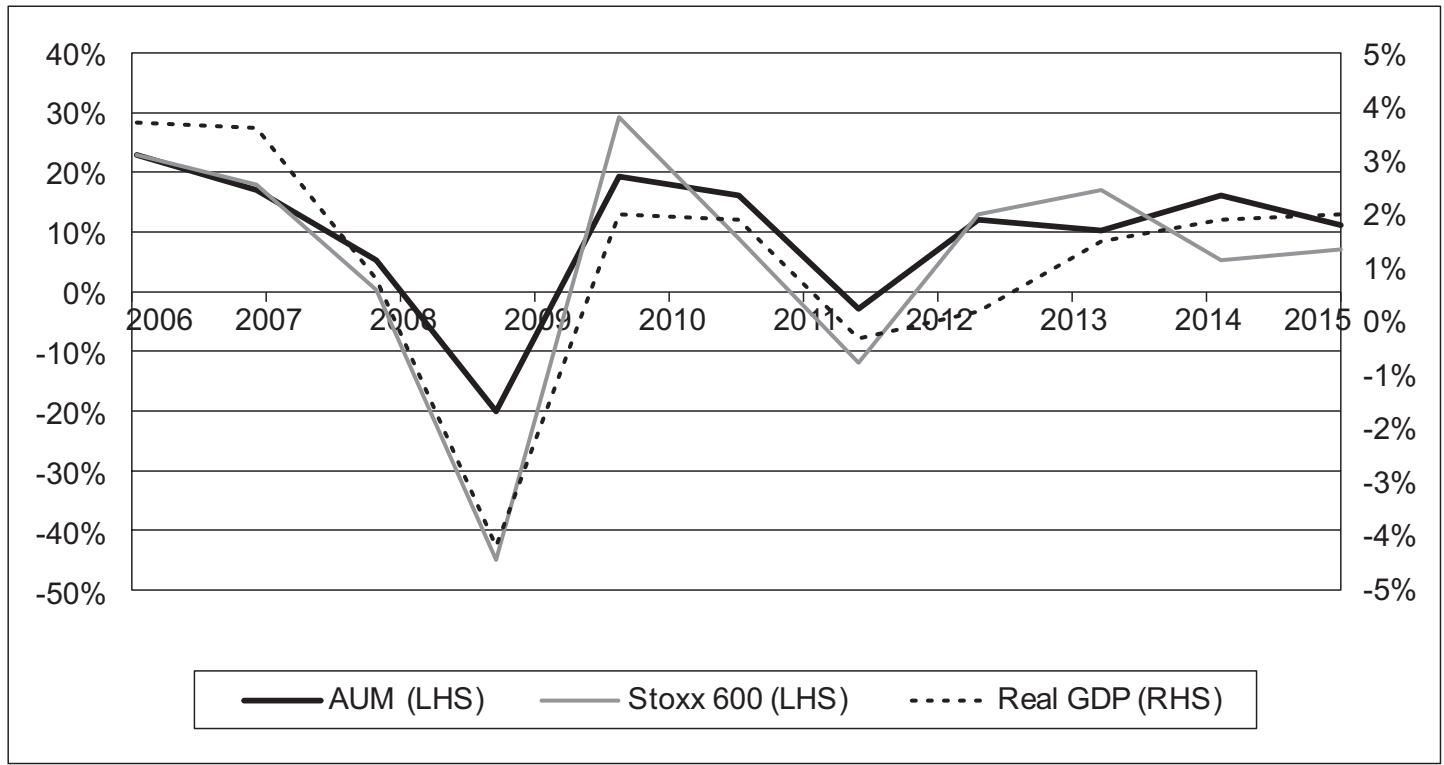

Source: own processing per available data in EFAMA Fact Book 2016

There is a strong correlation present between these three indicators. Inflation is also calculated in the figure 4 in form of real GDP. Except for real GDP, in the graph are AUM of European investment funds and stock benchmark index European Stoxx 600 consisting of six hundred biggest companies in the Europe. Time range is from 2005 to 2015.

In the last ten years two main events took place including financial crisis peaking in 2009, Greece crisis peaking in 2012 and strong recovery afterwards. Stoxx 600 equity index tends to be most volatile and real GDP is the most stable variable.

Another important thing is the allocation of European AUM in individual countries. This indicator is influenced by size of the country and number of inhabitants. Better way of interpretation of size of the market is therefore AUM/GDP indicator. 
Tab 1.

BIGGEST ASSET MANAGEMENT MARKETS IN THE EUROPE (END OF 2015, BILLION USD)

\begin{tabular}{|l|c|c|c|c|}
\hline Country & AUM & Market share & GDP & AUM/GDP \\
\hline Luxembourg & 3786.48 & $26.30 \%$ & 60.9 & $6217.5 \%$ \\
\hline Ireland & 2049.84 & $14.24 \%$ & 307.9 & $665.7 \%$ \\
\hline Germany & 1867.32 & $12.97 \%$ & 3494.9 & $53.4 \%$ \\
\hline France & 1816.56 & $12.62 \%$ & 2488.2 & $73.0 \%$ \\
\hline Great Britain & 1602.72 & $11.13 \%$ & 2649.8 & $60.5 \%$ \\
\hline Netherland & 792.72 & $5.51 \%$ & 769.9 & $103.0 \%$ \\
\hline Italy & 314.28 & $2.18 \%$ & 1852.5 & $17.0 \%$ \\
\hline Austria & 181.44 & $1.26 \%$ & 387.2 & $46.9 \%$ \\
\hline Belgium & 137.16 & $0.95 \%$ & 470.1 & $29.2 \%$ \\
\hline Poland & 63.828 & $0.44 \%$ & 467.3 & $13.7 \%$ \\
\hline Hungary & 19.548 & $0.14 \%$ & 117.1 & $16.7 \%$ \\
\hline Czech Republic & 8.424 & $0.06 \%$ & 193.5 & $4.4 \%$ \\
\hline Slovakia & 6.156 & $0.04 \%$ & 90.2 & $6.8 \%$ \\
\hline Slovenia & 2.484 & $0.02 \%$ & 44.1 & $5.6 \%$ \\
\hline Europe - other & 1747.44 & $12.14 \%$ & 3716.9 & $47.0 \%$ \\
\hline TOTAL & $\mathbf{1 4 3 9 6 . 4}$ & $\mathbf{1 0 0 . 0 0 \%}$ & $\mathbf{1 7 1 1 0 . 5}$ & $\mathbf{8 4 . 1 \%}$ \\
\hline
\end{tabular}

Source: own processing per available data from EFAMA 2016, IMF 2016

In the USA, for comparison, AUM is in mill. USD at 19317 and GDP is 18561. AUM/GDP indicator can be calculated at 104.1\%. Whole Europe has AUM/ GDP $84.1 \%$. It can be stated that USA is a bigger market, not just in overall size but also in the comparison to gross domestic product. Another important AUM markets are in Luxembourg and Ireland, where are many domiciles of mutual funds that are, in terms of single market, sold in all countries of the European Union. These countries are preferred mainly because of attractive tax policies and lower tax rates.

Three biggest European countries, Germany, France and Great Britain have AUM on GDP indicator in range from 53 to $73 \%$. In terms of countries of Cen- 
tral Europe, it can be stated that asset management markets are not yet fully developed. Czech Republic, Slovakia and Slovenia have AUM/GDP indicator under $10 \%$ which points at a big potential for further growth.

\subsection{Changing monetary policy of ECB}

As a response to global financial crisis the Federal Reserve lowered its interest rate from $5.25 \%$ to $0.25 \%$ and the European Central Bank from $4.25 \%$ to $0.00 \%$. Pace of the decrease was more dynamic in the case of Federal Reserve (less than a year) and slower from the side of the ECB. European Central Bank was lowering its rates in two periods as a response to global financial crisis (to 1.00\%) and later on Greece crisis (to $0.00 \%$ ). Whole process took more than five years.

Nowadays, the situation is similar, and FED is keeping faster pace in tightening of the monetary policy. It raised the rates in December 2015, followed by hikes in December 2016, March 2017, June 2017 and December 2017 to the current $1.50 \%$ with long-term goal of $3.00 \%$ interest rate that may be reached before 2020 . Current inflation in the USA as of December 2017 was $2.1 \%$ which is very close to the goal of the Federal Reserve (FED, 2017).

Situation in the Europe is different as the inflation in the Eurozone was, as of December 2017, 1.4\% which is still lower than the $2 \%$ goal of ECB. European Central Bank prolonged its quantitative easing program from December 2017 to September 2018 and cut the previous monthly purchase of 60 billion EUR to 30 billion. Governor of the ECB Mario Draghi stated that they will take further decisions on quantitative easing as the time goes. He stated as well that it will depend mainly on the current inflation and its further outlook. ECB lowered its inflation projections for the coming years and nowadays is not expecting the inflation to reach its target of $2 \%$ in 2018 or 2019. That is also signalizing that the rate hikes from ECB are still pretty far away (ECB, 2017).

Another concern is increasing strength of euro against dollar. It advances from low of 1.04 in December 2016 to 1.25 in January 2018. That represents a 20\% increase which is a very big movement for major currency pair in a short period of time. Strong euro can lead to lower exports from the Eurozone because goods are becoming relatively more expensive abroad. 
Fig 9.

ECB GDP GROWTH AND INFLATION FORECAST FOR THE EUROZONE

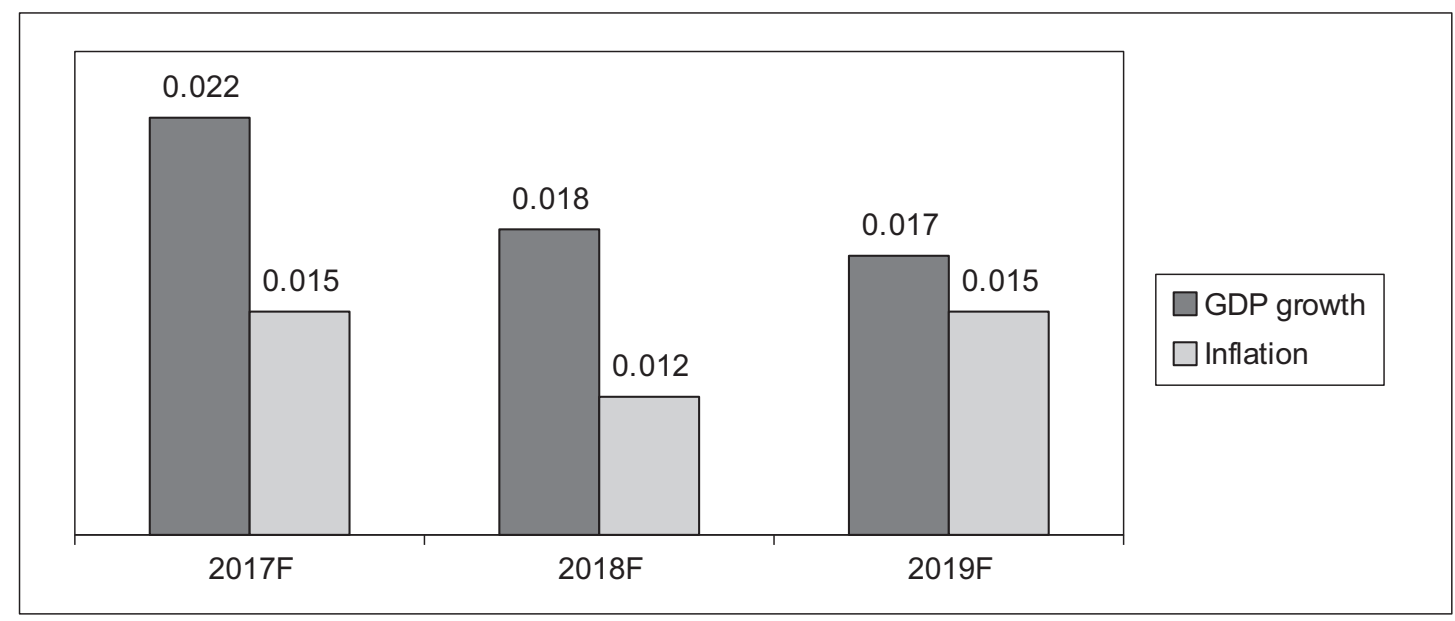

Source: European Central Bank, 2017

\section{CONCLUSION}

Assets under management in Europe are steadily increasing. The recovery after the financial crisis is strong and continuous. Assets under management in Europe fell from the pre-crisis peak of 8.5 trillion dollars to 6.8 trillion dollars in the year 2008. Nowadays is the value of AUM in Europe over 14.4 trillion dollars. This increase was supported by faster GDP growth, strong employment rate and accommodative monetary policy.

The speed of the recovery was faster than in the past. It took German equity index DAX 30 six years to recover to pre-crisis peak in financial crisis while it was seven years in the case of the dot-com bubble. The results from the analytical part of the article also pointed to the important difference between dot com bubble and global financial crisis, where stock equities decreased by the higher scale in case of dot com bubble, although there was no recession in terms of gross domestic product. Global financial crisis from 2007 to 2009 was associated with the worldwide recession and a decrease of GDP as well.

The shift in the monetary policy of European Central Bank is currently a very important aspect for the future prediction of the European asset management. ECB is cautious and wants to increase interest rates only slowly to limit inflation 
if it starts to increase over its $2 \%$ goal. European Central Bank is using its forward guidance approach to prepare the markets well in advance to prevent any kind of financial shock. Further strength or weakness of the euro will play an important role as well since it affects the competitiveness of European companies in terms of exports (Kohler and Ferjani, 2018).

All these mentioned risks and others including Brexit and global outlook are challenging future growth of AUM in Europe. Solid GDP growth and further potential for AUM growth in the Europe as a whole as well as emerging countries of Central and East Europe are off-setting these risks and justify current valuations.

\section{References}

ARNER, D. W., BARBERIS, J., \& BUCKLEY, R. P. 2015. The evolution of Fintech: A new post-crisis paradigm. Geo. J. Int'l L., 47, 1271.

BLOOMBERG. 2018. DAX Quote - Deutsche Boerse AG German Stock Index $D A X$. [Online]. Available at: http://www.bloomberg.com/quote/DAX:IND. [Accessed: 2018, February 12].

BOARD OF GOVERNORS OF THE FEDERAL RESERVE SYSTEM. 2017. The Fed - Meeting calendars and information. [Online]. Available at: http:// www.federalreserve.gov/monetarypolicy/fomccalendars.htm. [Accessed: 2017, September 26].

CARHART, M. M. 1997. On persistence in mutual funds performance. The Journal of Finance, 52(1): 57-82.

CARROLL, A., SCIAMARELLI, A. and DELBECQUE, B. 2016. Trends in European investment funds - Fact book. $14^{\text {th }}$ edition. Brussels: European Fund and Asset Management Association (EFAMA).

CHOVANCOVA, B. and ZOFCAK, S. (2012). Kolektivne investovanie. 1st ed. Bratislava: Wolters Kluwer.

CILIKOVA, J. and AMBRA, T. (2013). Regulacia fondov sa rozsiruje. In BIATEC Narodnej banky Slovenska. ISSN 1335-0900.

DRAGHI, M. 2017. Monetary policy decisions. [Online]. European Central Bank. Available at: http://www.ecb.europa.eu/mopo/decisions/html/index.en.html. [Accessed: 2017, September 15].

DE SANTIS, R. 2012. The Euro area sovereign debt crisis: safe haven, credit rating agencies and the spread of the fever from Greece, Ireland and Portugal. ECB Working Paper, No. 1419. 
EUROPEAN CENTRAL BANK. 2017. [Online] Available at: http://www.ecb.europa.eu/press/govcdec/mopo/2017/html/index.en.html. [Accessed: 2017, September 24].

EUROPEAN COMMISSION, (2017). Investment services and regulated markets - Markets in financial instruments directive (MiFID). [online] Available at: https://ec.europa.eu/info/business-economy-euro/banking-and-finance/financial-markets/securities-markets/investment-services-and-regulated-marketsmarkets-financial-instruments-directive-mifid_en [Accessed 28 Aug. 2017].

EUROPEAN COMMISSION (2018). Undertakings for the collective investment in transferable securities (UCITS) - Directive 2009/65/EC. [online] Available at: https://ec.europa.eu/info/law/undertakings-collective-investment-transferable-securities-ucits-directive-2009-65-ec_en [Accessed 10 Apr. 2018].

EUROSTAT. 2018. Database - Eurostat. [Online]. Available at: http://ec.europa. eu/eurostat/data/database. [Accessed 2018, February 12].

GLADIS, D. 2009. Naucte se investovat. 2nd ed. Prague: Grada Publishing.

HEALY, J. and DELBECQUE, B. 2011. Trends in European investment funds Fact book. $9^{\text {th }}$ edition. Brussels: European Fund and Asset Management Association (EFAMA).

HEALY, J., BREDA, A. and DELBECQUE B. 2013. Trends in European investment funds - Fact book. 11 ${ }^{\text {th }}$ edition. Brussels: European Fund and Asset Management Association (EFAMA).

INTERNATIONAL MONETARY FUND. 2017. World Economic Outlook Database April 2016. [Online] Available at: http://www.imf.org/external/pubs/ft/ weo/2016/01/weodata/index.aspx. [Accessed 2017, October 30].

KOHLER, A. and FERJANI, A. 2018. Exchange rate effects: A case study of the export performance of the Swiss Agriculture and Food Sector. The World Economy, 41(2): 494-518.

KOUKI, M.; BELHADJ, R. and CHIKHAOUI, M. 2018. Impact of Financial Crisis on GDP Growth: The Case of Developed and Emerging Countries. International Journal of Economics and Financial Issues, 7.6: 212-221.

MATUSOVIC, M. and MATUSOVICOVA, M. 2010. Vplyv financnej krizy na buducnost odvetvia kolektivneho investovania v Slovenskej republike. Ekonomicky casopis, 58: 770-785.

LEMESHKO, O. and REJNUS, O. 2015. Performance Evaluation of Equity Mutual Funds in Countries with Emerging Economies: Evidence from BRIC, CEE, sea and MENA Regions. Procedia Economics and Finance, 30: 476-486.

LEVINE, R. and ZERVOS, S. 1998. Stock markets, banks, and economic growth. American economic review, 88(3): 537-558. 
LOOK, C. 2017. Draghi Says Euro a Concern as ECB Targets October Decision on $Q E$. [Online]. Bloomberg.com. Available at: http://www.bloomberg. com/news/articles/2017-09-07/draghi-says-euro-gain-must-be-monitored-assource-of-uncertainty. [Accessed 2017, October 15].

MARKOWITZ, H. M. 1991. Foundations of portfolio theory. The journal of finance, 46(2): 469-477.

PISANI-FERRY, J. et al. 2016. Europe after Brexit: A proposal for a continental partnership. Brussels: Bruegel.

TIDWELL, G. (2014). Building blocks for industry driven investor education initiatives. [online] International Organization of Securities Commissions. Available at: https://www.iosco.org/library/speeches/pdf/201403-GaryTidwell.pdf [Accessed 5 Sep. 2017].

YELLEN, J. 2017. The Fed - Press Releases. [Online]. Federalreserve.gov. Available at: http://www.federalreserve.gov/newsevents/pressreleases.htm. [Accessed 2017, October 10].

\title{
OPORAVAK EUROPSKOG INVESTICIJSKOG FONDA DESET GODINA NAKON FINAN- CIJSKE KRIZE
}

\author{
Summary
}

U radu se analizira tekuća situacija europskog investicijskog fonda nakon financijske krize 2007-09 i uspoređuje s razlikama krize dionica internetskih poduzeća u 2000-03. Uspoređuje europski investicijski fond sa globalnom situacijom kao i sa europskim makroekonomskim pokazateljima, uključujući bruto domaći proizvod i zaposlenost. Analiza je potpomognuta usporedbom reakcija financijskog tržišta i bruto domaćeg proizvoda na krizu dionica internetskih poduzeća i financijsku krizu. Rezultati analize pokazuju da se industrija u potpunosti oporavila od financijske krize, sa stanjem europskog investicijskog fonda znatno iznad vrhunca prije krize. Dionički investicijski fondovi danas su najpoželjnija vrsta zajedničkog fonda u eurozoni, a slijede obveznički investicijski fondovi. To ukazuje na povećani i obnovljeni apetit investitora nakon krize. Na kraju je članak potpomognut drugim važnim aspektima imovine investicijskih fondova u Europi kao promjenom monetarne politike Europske središnje banke i Federalnih rezervi.

Ključne riječi: europski investicijski fondovi, financijska kriza, zajednički fond, kriza dionica internetskih poduzeća, makroekonomska analiza 